\title{
Chapter 10 \\ Reconsideration of the Antiquity of the Middle Palaeolithic Footprints from Theopetra Cave (Thessaly, Greece)
}

\author{
Nina Kyparissi-Apostolika and Sotiris K. Manolis
}

\begin{abstract}
During the 1996 field season, four footprints were found in undisturbed deposits at the borders of squares $\Theta 10-\mathrm{I} 10$ at a depth of $3.5 \mathrm{~m}$ at the Theopetra Cave excavation site. The footprints lie adjacent to an ash horizon that has been dated to ca $\sim 135 \mathrm{ka}$. Two footprints in the trail are complete and measure $150.4 \mathrm{~mm}$ and $138.96 \mathrm{~mm}$ in length. Based on modern European standards, these lengths would be consistent with young children aged between 2 and 4 years old and 90-100 cm in stature. The two complete footprints, which follow each other in the trail, appear both to have been left feet. The partial print, which immediately precedes the two complete prints in the series, also appears to have been by a left foot. This suggests that what initially seems to be a single trail is actually a composite of two or more trails of prints. This hypothesis is supported by the different characteristics of the two complete prints. One is consistent with a bare foot and clearly shows the impressions of the toes, ball, arch and heel. The other is characterized by a simpler contour and is more sharply defined and indicates that the individual was wearing some kind of foot covering. An important question is what kind of hominid made the footprints? These footprints may have been made by Neanderthals or early Homo sapiens, based on thermoluminescence dating results.
\end{abstract}

Keywords Footprints · Early Homo sapiens $\cdot$ Neanderthals $\cdot$ Middle Pleistocene Theopetra Cave · Europe · Greece

\footnotetext{
N. Kyparissi-Apostolika $(\bowtie)$

Ephorate of Palaeoanthropology and Speleology, Ministry of Culture, Athens, Greece

e-mail: nkyparissi@hotmail.com

S. K. Manolis

Department of Animal and Human Physiology, Faculty of Biology, National and Kapodistrian

University of Athens, Athens, Greece

e-mail: smanol@biol.uoa.gr
} 


\section{Introduction}

Theopetra Cave $\left(21^{\circ} 40^{\prime} 46^{\prime \prime} \mathrm{E}, 39^{\circ} 40^{\prime} 51^{\prime \prime} \mathrm{N}\right)$ is a unique prehistoric site in central Greece (Fig. 10.1), as several cultural periods (Middle and Upper Palaeolithic, Mesolithic and Neolithic) are represented (Kyparissi-Apostolika 1998, 1999; Facorellis et al. 2001; Karkanas 2001).

Excavations at Theopetra Cave have produced many significant anthropological findings, among which the prehistoric footprints are distinctive. During the 1996 field season, four footprints were found in undisturbed deposits in square $\Theta 10$ at a depth of $3.5 \mathrm{~m}$ (Fig. 10.2) (Manolis et al. 2000). The footprints lie adjacent to an ash horizon that has been dated to ca $\sim 130 \mathrm{ka}$ (new date after Valladas et al. 2007). These

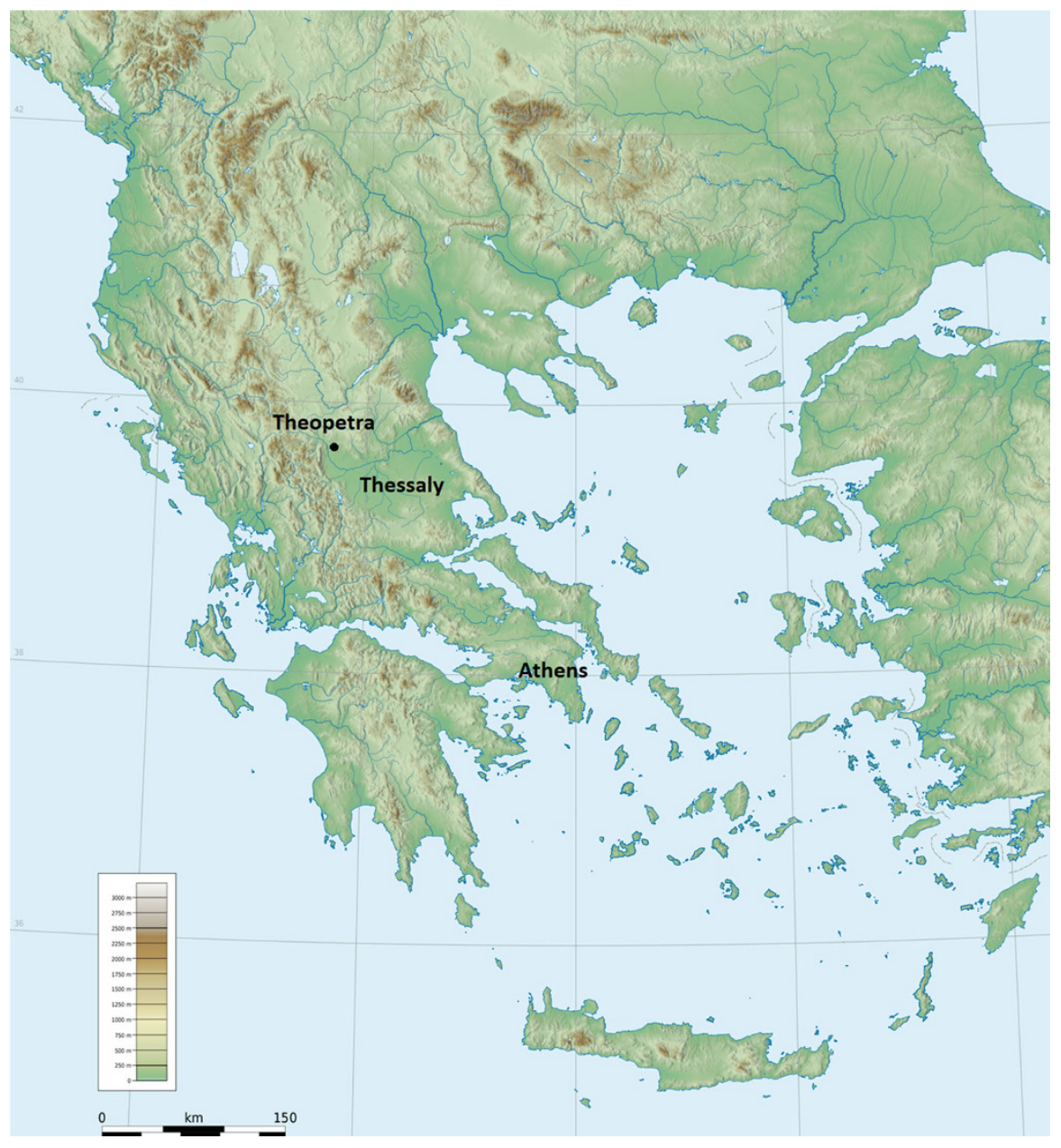

Fig. 10.1 Map of Greece showing the site of Theopetra Cave 


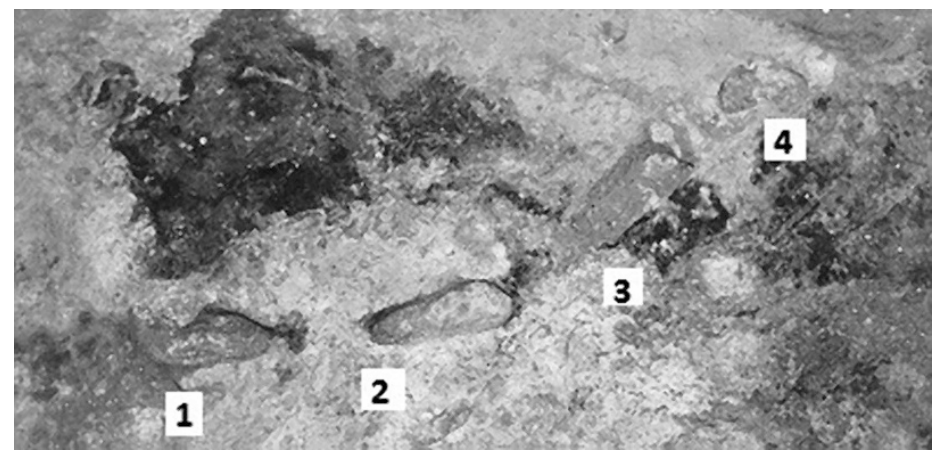

Fig. 10.2 The footprints found in the Theopetra Cave

footprints were found among others printed in an extensive ashy and burnt area of five serial trenches in axis 10 of the excavation grid $(\mathrm{Z} 10, \mathrm{H} 10, \Theta 10, \mathrm{I10}, \mathrm{K} 10), 16$ to $20 \mathrm{~m}^{2}$. Most of the remaining footprints rather belong to animals, but the presence of a few more human ones among them cannot be excluded (Fig. 10.2).

In palaeoanthropology it is well understood that we cannot know in detail the behaviour of upright body posture and bipedalism. Our inferences concerning the shaping of the body and the way of walking are derived from comparing data after following a logical sequence of thoughts. These are based mostly on the hypothesis of the homology of various anatomic characteristics.

The footprints are an undeniable proof of the existence of hominids and/or prehistoric humans in general, and we can draw from them very important information about locomotion and composition of the group, through comparative and experimental methods.

Such information might be (after Day 1991):

- Morphological: Because in palaeoanthropology the findings are mostly hard fossilized bones - the discovery of footprints may give us information about the shape of the soft parts of the foot and the size and morphology of its anatomical picture. This includes the position of the metatarsal area, the heel, the toes, their prominence and the presence of an arch. The measurements allow us to estimate the size and compare it to that of other known human populations. The stature may also be estimated from world data where the length of the foot is approximately $15 \%$ of the height.

- Behavioural: By studying the footprints we can make inferences about the way of walking, whether the individual was running at the time the footprints were made, and we can also estimate the pace. Of course, this is not always possible, because it is required that the series of steps lies undisturbed, like in the case of Laetoli, Tanzania.

- Environmental: Together with the human footprints there could be others made by animals, in which case we will be able to assume if they are contemporary with 
each other. Related botanical data will allow us to recreate the climatic and environmental conditions at the given time.

\section{Historical Background}

The most ancient footprints in the world are the ones discovered in Laetoli, Tanzania, and have been dated to 3.7 Ma. Therefore, when footprints are discovered, some of the questions that need to be answered can be: Who were the hominids that created them? Were they male or female and of what age? How tall were they? How much did they weigh? Some of these questions may be answered, but comparative data are required. Next, we will see which of these we have been able to answer through our research so far.

The most ancient footprints in Europe were found at Happisburgh, UK, dated to the Early Pleistocene (ca 1-0.78 Ma) (Ashton et al. 2014). The following caves or open-air sites have been dated to the Middle Pleistocene: Roccamonfina, Italy, 325,000-385,000, open air (Avanzini et al. 2004, 2008); Terra Amata, France, 300,000-400,000, open air (de Lumley 1966, 1967); and Theopetra Cave, Greece, ca 130,000, cave (Manolis et al. 2000).

Late Pleistocene sites are caves such as the Vârtop Cave in Romania dated $62 \mathrm{ka}$ (Onac et al. 2005); the Grotta del Cavallo in Italy (the first known appearance of anatomically modern humans in Europe, 44 ka (Benazzi et al. 2011); and several caves in France such as Lascaux, Niaux, Aldene, Peche Merle, Fontanet, Ariège and Chauvet, Bàsura in Italy and Ojo Guareña in Spain (Lockley et al. 2008). All these sites except the Vârtop Cave and Grotta del Cavallo have been dated below 30,000 years and therefore are undoubtedly the trails of anatomically modern humans. The footprints of children seem to be an important component of the trail record of Palaeolithic caves. For example, Chauvet Cave in southern France revealed a trail of footprints of a young boy (8 years old and $1.5 \mathrm{~m}$ tall) (Harrington 1999). Niaux is of significant interest because it includes footprints that may represent children (Pales 1976). In the Réseau Clastres, three trails of children are recorded (Lockley et al. 2008). In the Bàsura Cave in Italy, (Chiapella 1952; see Chap. 14) Late Pleistocene tracks of children were found.

\section{Materials and Methods}

After the necessary cleaning process took place, the footprints were copied and photographed, and a negative cast was created. Positive casts of the footprints were also created for the necessity of research (mapping). The questions arising are of the same kind as the ones mentioned earlier. Nevertheless, a more thorough observation revealed that all four footprints were made by left feet, and this caused one more 
question to rise: are these solitary footprints or trails of steps crossing each other, some of which have been lost?

The suggestion that we are before a series of steps made by different individuals is considered the most possible, since the first two prints were made by a foot with some kind of covering, the third has been made by a bare foot, whereas the fourth one is not clearly distinguished, either because it has been rotated or because other footprints have been made on it.

\section{Chronology - Dating}

Ten burnt flint specimens unearthed from the lower part of the Middle Palaeolithic sequence of the cave (layers II2 and II4) were dated by thermoluminescence (TL), which gave dates ranging between $\sim 110$ and $135 \mathrm{ka}$ (Valladas et al. 2007). The positions of the TL-dated samples are shown in Fig. 10.3. These results are not consistent with the earlier ${ }^{14} \mathrm{C}$ dates (Facorellis and Maniatis 1999), as they support a much later date for these layers (Facorellis et al. 2013). Facorellis and his colleagues (2013) note that the depositional sequence of Theopetra Cave is complex with frequently appearing filled channels and underground tunnels as well as labyrinthine large burrows. It is well established by sediment micromorphological analysis that

Fig. 10.3 Stratigraphic profile of the trench $\mathrm{I} 10$ showing the position of the samples. (After Facorellis et al. 2013)

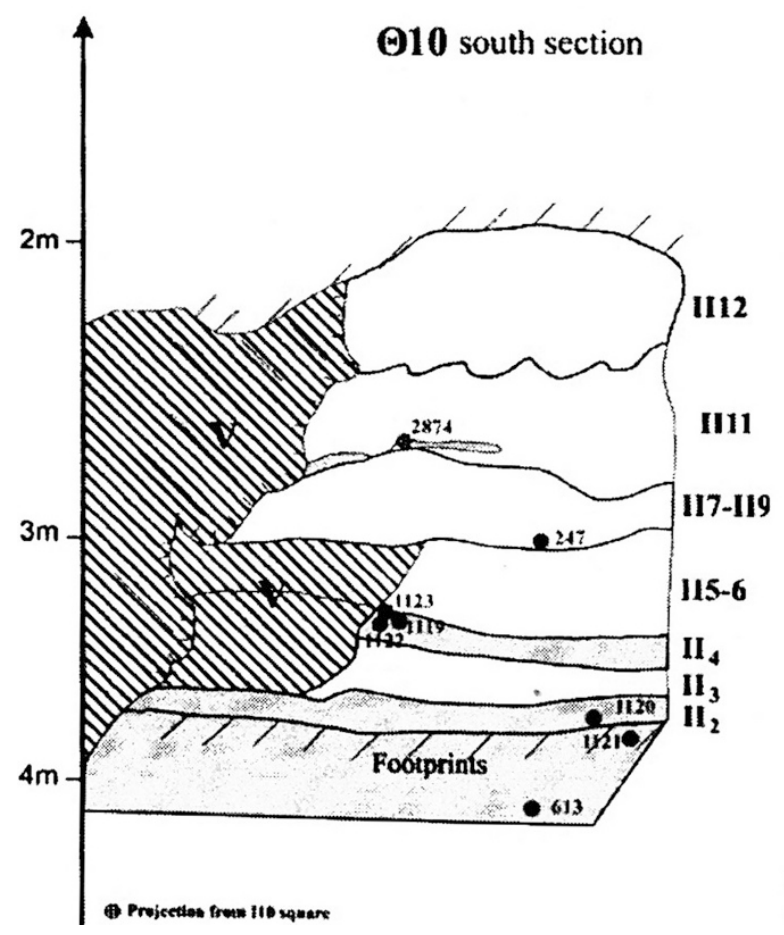


the Pleistocene sediments underwent an intense diagenetic mechanical and chemical alteration related to the cave's hydrological conditions.

Comparison between the ${ }^{14} \mathrm{C}$ dates with the much older TL dates of 11 burnt flint specimens indicates that most of the charcoal samples have been contaminated by a progressively increasing unidentified amount of exogenous carbon, thus yielding more recent dates (Facorellis et al. 2013).

\section{Archaeology - Lithic Artefacts}

The Middle Palaeolithic (II1-8) is represented by the most clearly stratified lithic deposits. The principal characteristic of the layer II2 lithic industry is the use of the Levallois technique for production of a wide range of tool types. The assemblages from layer II4 bear technological and morphological characteristics often encountered in the terminal Middle Palaeolithic industries of the Balkans and the Near East. Their principal characteristic is the use of both Levallois unipolar and prismatic bipolar core reduction strategies. The tool inventory of Theopetra Cave contains Middle and, to a lesser extent, Upper Palaeolithic types (Panagopoulou 1999, 2000).

\section{Description of the Footprints}

A detailed examination disclosed that all four footprints were made by left feet, and it remains unresolved whether these are solitary footprints or continuous trails of steps crossing each other where some intermediate steps are missing. There are four footprints. The first footprint in the trail (No 1) lacks the posterior half of the foot and had been made by a covered foot. The second is complete (Fig. 10.4a) and was also created by a covered foot. Although the footprint is restricted due to the covering material (footwear), we can clearly observe the arch region and the support lines at the external region of the foot. The distance between these two left footprints is small $(25 \mathrm{~cm})$, so there is not enough space for the right footprint, which is not preserved. This led us to suppose that they belong to different individuals. The third is also complete but has been made by a bare foot (Fig. 10.4b). The big toe, the ball, the arch and the heel region are evident in the footprint. The last one is disturbed, and it is very difficult to be analysed.

Two methods of analysis have been used, which led to almost the same results, stereophotography and photogrammetry. The latter was used by M. Day for the analysis of various footprints from Laetoli (Tanzania), Niaux Cave (France), Bàsura Cave (Italy), and Uskmouth (Great Britain). Both methods include the creation of contour lines (mapping).

However, when we evaluated this method, we estimated it would be quite difficult to produce an illustration of the contours. This means that the researchers might miss important parts of the contours (in different altitudes), and so they would 


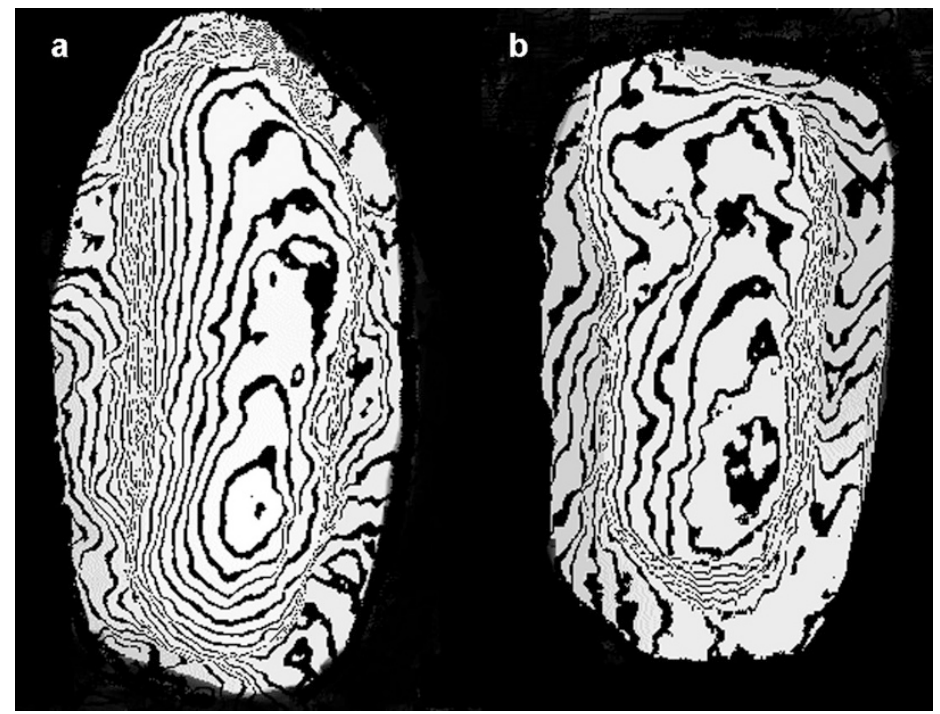

Fig. 10.4 Contours shaped by 3D laser scanning of the Theopetra footprints; (a) Theopetra No 2; (b) Theopetra No 3

have to fill them in, without being certain that the additions were correct. It was therefore decided (see Manolis et al. 2000) to illustrate the contours of the studied footprints by using a 3D laser scanner, and the results were indeed impressive. It should also be noted that this method was innovative, the software was still under development, and this was the first official application in anthropological material. Subsequent studies mainly use 3D laser scanner in the study of footprints.

The length and width of the footprints were measured as well, so that they could be compared to data from contemporary humans. The formulae for the estimation of height when sex and age are unknown (as in this case) are the following (after Grivas et al. 2008):

$$
\begin{aligned}
& \text { Height }(\mathrm{cm})=17.369+5.879 \times[\text { right foot length }(\text { in } \mathrm{cm})] \\
& \text { Height }(\mathrm{cm})=17.592+5.861 \times[\text { left foot length }(\text { in } \mathrm{cm})]
\end{aligned}
$$

Another formula is the estimation of stature by the foot length as a percentage of body height. The percentage may vary from $14 \%$ to $16 \%$ according to the population measured, although the traditional figure quoted is $15 \%$ (Topinard 1877). This formula applies to both sexes and individuals of all ages. However, when calculating the size of the foot from footprints rather than contours (footwear), there is a difference of $1 \%$, meaning that the length of the foot is $14 \%$ of the height and not $15 \%$, with a variation of $\pm 25.4 \mathrm{~mm}$ (Robbins 1985,1986 ). 


\section{Results}

\section{Contour Analysis (3D Laser Scanner)}

In order to proceed with our study, we needed to gather data from the contemporary Greek population. For this first stage, footprints from three subadults (one male and two females) were collected. Comparing the contours of the footprints to those of contemporary juveniles revealed that the former belong to human children.

We can easily see the typical form of the human footprint in the prints of Theopetra No 2 and 3 in comparison to the prints produced by contemporary children. This comparison was done in order to prove what seemed to be well understood: that the ancient footprints belonged to human beings.

The footprint (Fig. 10.5a) was made by a female whose left foot was covered by three thin stockings, and thus we recreated a print by a covered foot. Notice the resemblance in the pattern in both prints (Theopetra No. 2 (Fig. 10.5b) and contemporary female).

The footprint (Fig. 10.6a) was made by a male child (bare foot). Notice the similar pattern (ball, arch and the heel region) with the No 3 footprint of Theopetra (Fig. 10.6b).

All measurements confirm the first suggestion and leave us with no doubt that they are the footprints of young children (Table 10.1).

This seems highly unlikely. By comparing the length of the feet, we can make the following suggestions.

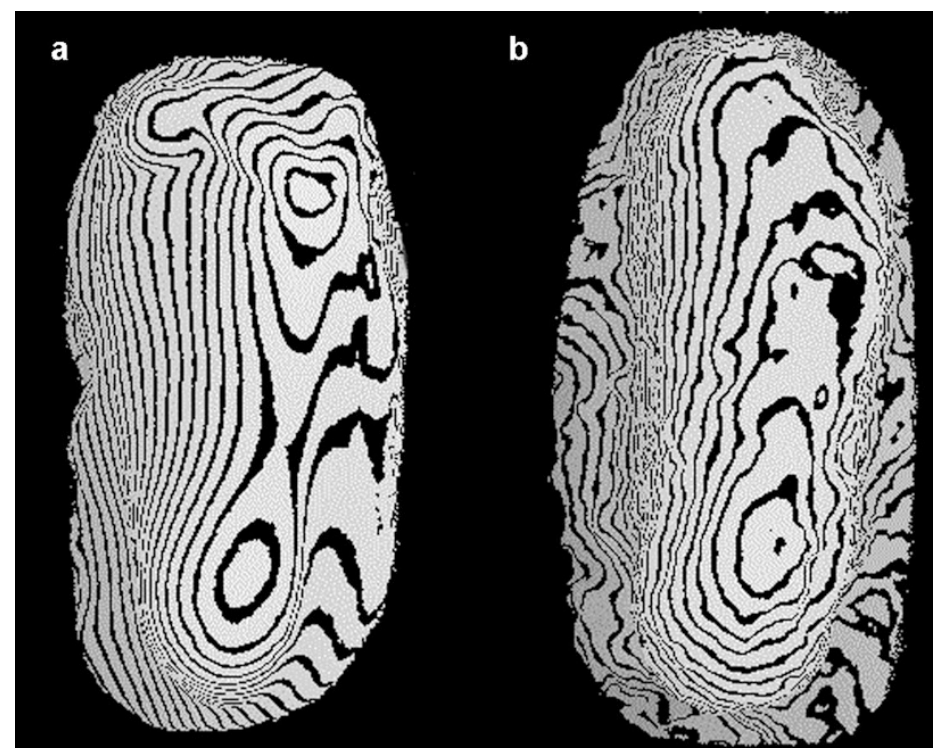

Fig. 10.5 Contour of the footprint created by covered foot of female, 3 years old (a), and the No 2 footprint of Theopetra Cave (b). Note the almost similar pattern in the heel and toe region 


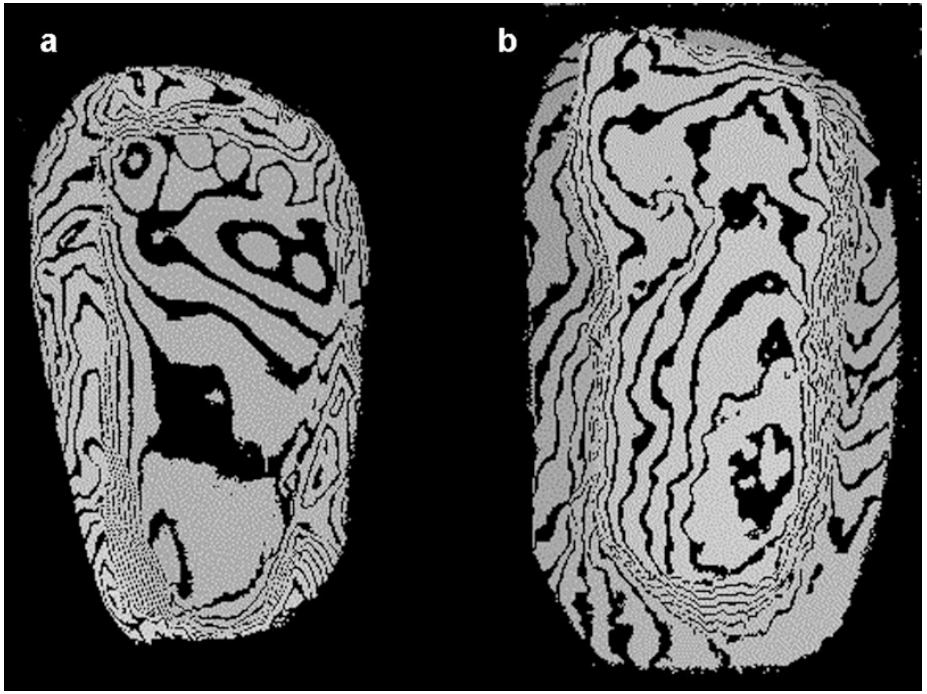

Fig. 10.6 Contour of the footprint created by the bare foot; (a) modern child; (b) No 3 footprint of Theopetra Cave. Note the similarity in the pattern of the toes, ball, arch and heel regions

Table 10.1 Measurements of the complete Theopetra footprints and the reference sample of modern Greek children (in mm)

\begin{tabular}{l|l|l|l|l|l}
\hline Variables & $\begin{array}{l}\text { Theopetra } \\
\text { No 2 }\end{array}$ & $\begin{array}{l}\text { Theopetra } \\
\text { No 3 }\end{array}$ & $\begin{array}{l}\text { Modern female } \\
\text { (2 years old) }\end{array}$ & $\begin{array}{l}\text { Modern male } \\
\text { (3 years old) }\end{array}$ & $\begin{array}{l}\text { Modern male } \\
\text { (3 years old) }\end{array}$ \\
\hline $\begin{array}{l}\text { Foot } \\
\text { length }\end{array}$ & 150.86 & 138.11 & 140.2 & 142.9 & 165.0 \\
\hline $\begin{array}{l}\text { Heel } \\
\text { width }\end{array}$ & 47.28 & 51.17 & 33.84 & 35.19 & 40.33 \\
\hline $\begin{array}{l}\text { Ball } \\
\text { width }\end{array}$ & 54.03 & 62.82 & 58.94 & 55.39 & 62.0 \\
\hline
\end{tabular}

\section{Sex and Age}

Footprint No. 2: If a male (young boy) made the footprint, then it should be a child of about 3 years. If, on the other hand, a female made it, it should be between 3 and 4 years of age. Note that we should be particularly careful in our final statements, because a covered foot created the print, and so measurements may not necessarily correspond to the actual dimensions. This means that the print is actually bigger than the foot that created it. Footprint No 3: this bare footprint was made by a child between 2 and 2.5 years of age, regardless of sex.

The comparison with mean values of Muller et al. (2012) reveals that most probably the two footprints (No 2 and No 3) were made by children aged 3 and 2 years, respectively. Nevertheless, an older age can't be excluded as a result of volume reduction due to diagenesis. 


\section{Stature}

From the footprints available, the ones that provide us with more information are No 2 and No 3.

The stature for the individual 2 falls in the range 97.3-106.5 $\mathrm{cm}$ (Robbins 1985, 1986). Applying the percentage of $15 \%$ (Topinard 1877), a height of $100.6 \mathrm{~cm}$ was estimated. Finally, the application of the formula of Grivas and his colleagues (2008) gave a stature of $106.0 \mathrm{~cm}$.

The individual that left the bare footprint No 3 probably was a child between 2 and 2.5 years of age, either male or female. The stature falls in the range 89.1-97.5 cm (Robbins 1985, 1986). Applying the percentage of 15\% (Topinard 1877), a height of $89.1 \mathrm{~cm}$ was estimated. The application of the formula of Grivas and his colleagues (2008) gave a stature $98.5 \mathrm{~cm}$.

All these calculations are assumptions, because there are several uncertainties when working with footprints.

\section{Discussion}

From the results of our study thus far, we can summarize the following:

- Footprint size and form: We have limited knowledge about the rate of growth and development of Neanderthal children. Trinkaus (1983) implies that during the first year of their life, Neanderthal children are identical to the children of anatomically modern humans, but this is based mostly on cranial remains. We should also point out that the rate of maturation in Neanderthal children has challenged many scientists, and Dean et al. (1986) proposed that the rate of development in Neanderthal children may have been faster than that in the children of early modern humans. Another recent study of Rosas et al. (2017) notes that Neanderthals' growth rate is very similar to that of Homo sapiens, in general, but differences have been observed in the development of the brain and spine of these two human groups. These are the main conclusions of a study which focussed on Neanderthal child approximately 8 years old, who lived in the cave of El Sidrón (Spain).

- Foot function and footwear: Neanderthals used fire; they certainly buried their dead; they seem to have self-medicated with local plants; and they undoubtedly used foot coverings. It is very crucial to know whether the Neanderthals and early humans have the same foot function. Recently Bennett and his colleagues (2016) conclude that foot function has remained almost unchanged, perhaps experiencing evolutionary homeostasis, for the last 3.66 million years. The archaeological record has limited evidence of footwear. The most ancient evidence appears to be in Theopetra Cave. The footwear probably had significant use among Middle Palaeolithic humans, who may have had various forms of foot covering, to provide insulation and protection from cold weather and rough substrate 
(Trinkaus 2005). This phenomenon of footwear use must have been widespread although the archaeological findings are very rare.

- Age: Children between 2 and 4 years of age produced the footprints, bearing in mind that these children could belong to early Homo sapiens or Neanderthals. The analysis of the footprints gave a clear reconstruction of the facts that occurred at this time in the cave. Firstly, the cave was in use during the Middle Palaeolithic (Kyparissi-Apostolika 1999; Karkanas 2001; Valladas et al. 2007; Facorellis et al. 2013). There are traces of fire remnants on an ashy wet surface, and the footprints are very near these remnants. This could mean that the children were walking and playing in the area surrounding the hearth. We suppose that there are several trails (at least two) which were made by different individuals. The evidence that an individual who wore some kind of foot covering made the first two prints supports this. A bare foot has made the third print, whereas the fourth one is not clearly distinguished, either because it has been rotated or because other footprints have been made on it. The study of the footprints reconstructs and brings the children in our eyes: We can imagine these children playing in the cave and leaving their traces in the ashy wet surface around the burnt remnants.

- Neanderthal children or not? Through dating of specimens from the layer on which the footprints were found, it became obvious that at the specific time point early Homo sapiens and Neanderthals coexisted. The former make an appearance in Europe early, at about $210 \mathrm{ka}$ in Apidima Cave, Greece (Harvati et al. 2019). The latter resided in Europe, and their remains are found all over the continent. Evaluating all the available information, it is difficult to conclude what kind of individuals left these footprints. How do we know that they are Neanderthal children? We do not know this because the form and shape of the footprints are not consistent with the known anatomy of Neanderthals, from various other sites. Duveau et al. (2019: 19411) note, "They are relatively broader, especially in the midfoot, than the footprints made by Homo sapiens, which corresponds to a more robust foot and a less pronounced arch".

The fact that the footprints of Theopetra have been made by children aged 2-4 years would lead one to hypothesize that probably the foot at this age is not fully developed. On the other hand, the cultural findings (lithic artefacts) seem to be Mousterian (the typical technological expression of Neanderthals) and have led to the conclusion that the footprints were made by Neanderthal children.

\section{Conclusion}

Both the palaeoanthropological and archaeological records suggest that foot covering was present during the Middle Palaeolithic. The only evidence that helps us in this case for establishing chronology is the lithic material found in this layer. If eventually the assessment that the tools are Mousterian (Panagopoulou 1999, 2000) is confirmed, we will positively assume that they were Neanderthal children. But 
even if they turn out to be the children of early Homo sapiens, the significance of the findings is still great, since that would prove beyond reasonable doubt the presence of anatomically modern humans in Europe at approximately $~ 135$ ka much earlier of what was thought until now.

Acknowledgements We thank Dr. Tsitsiloni, Mrs. P. Alfieri and Mrs. E. Malliou (for the permission to cast their children's fee). In addition, many thanks to Mr. P. Polydoropoulos for casting the Theopetra footprints and Dr. I. Petroutsa and Mrs. H. Belte for their assistance. Finally, we thank Dr. P. Karkanas for his valuable information on how the footprints were preserved and Dr. C. Eliopoulos for the editing of the manuscript.

\section{References}

Ashton, N., Lewis, S. G., De Groote, I., Duffy, S. M., Bates, M., et al. (2014). Hominin footprints from early pleistocene deposits at Happisburgh, UK. PLoS ONE, 9(2), e88329-1-13.

Avanzini, M., De Angelis, M., Mietto, P., Panarello, A., \& Rolandi, G. (2004). Pleistocene human footprints preserved on a zeolite-rich pyroclastic flow (Roccamanfina, Italy). In International Union of Geological Sciences (Ed.), 32nd international geological congress (p. 598). Florence: Università di Firenze.

Avanzini, M., Mietto, P., Panarello, A., De Angelis, M., \& Rolandi, G. (2008). The devil's trails: Middle Pleistocene human footprints preserved in a volcanoclastic deposit of Southern Italy. Ichnos, 15, 179-189.

Benazzi, S., Douka, K., Fornai, C., Bauer, C. C., Kullmer, O., Svoboda, J., Pap, I., Mallegni, F., Bayle, P., Coquerelle, M., Condemi, S., Ronchitelli, A., Harvati, K., \& Weber, G. W. (2011). Early dispersal of modern humans in Europe and implications for Neanderthal behaviour. Nature, 479, 525-529.

Bennett, M. R., Reynolds, S. C., Morse, S. A., \& Budka, M. (2016). Footprints and human evolution: Homeostasis in foot function? Palaeogeography, Palaeoclimatology, Palaeoecology, 461, 214-223.

Chiapella, V. G. (1952). Orsi e nomini preistorici nella grotta della 'Strega', (Genova). Rivista del Comune, A29, 22-29.

Day, M. H. (1991). Bipedalism and prehistoric footprints. In Y. Coppens \& B. Sénut (Eds.), Origine (s) de la Bipedie chez les Hominides (pp. 199-213). Paris: Cahiers de Paleoanthropologie, Editions du CNRS.

De Lumley, H. (1966). Les fouilles de Terra Amata a Nice. Premiers rèsultats. Bulletin of the Museum of Anthropology and Prehistory of Monaco, 13, 29-51.

De Lumley, H. (1967). Découverte d'habitats de l'acheuléen ancien dans les dépôts mindéliens sur le site de Terra Amata, Nice, Alpes-Maritimes. Compte-Rendus de L'Académie des Sciences, 264, 801-804.

Dean, M. C., Stringer, C. B., \& Bromage, T. G. (1986). Age at death of the Neanderthal child from Devil's tower, Gibraltar and the implications for studies of general growth and development in Neanderthals. American Journal of Physical Anthropology, 70, 301-309.

Duveau, J., Berillon, G., Verna, C., Laisné, G., \& Cliquet, D. (2019). Neanderthal children's footprints offer rare snapshot of Stone Age family life. PNAS, 116(39), 19409-19414.

Facorellis, Y., \& Maniatis, Y. (1999). Possibilities and accuracy of radiocarbon dating in the Palaeolithic period. British School at Athens Studies, 3, 179-189.

Facorellis, Y., Kyparissi, N., \& Maniatis, Y. (2001). The Cave of Theopetra, Kalambaka: Radiocarbon evidence for 50,000 years of human presence. Radiocarbon, 43(2B), 1029-1048. 
Facorellis, Y., Karkanas, P., Higham, T., Brock, F., Ntinou, M., \& Kyparissi-Apostolika, N. (2013). Interpreting radiocarbon dates from the Paleolithic layers of Theopetra Cave in Thessaly, Greece. Radiocarbon, 55(2-3), 1432-1442.

Grivas, T., Mihas, C., Arapaki, A., \& Vasiliadis, E. (2008). Correlation of foot length with height and weight in school age children. Journal of Forensic and Legal Medicine, 15, 89-95.

Harrington, S. P. M. (1999). Human footprints at Chauvet Cave. Archaeology, 52(5) www.archae ology.org/9909/newsbriefs/chauvet.html. Accessed 14 Jan 2020.

Harvati, K., Röding, C., Bosman, A. M., Karakostis, F. A., Grün, R., Stringer, C., Karkanas, P., Thompson, N. C., Koutoulidis, V., Moulopoulos, L. A., Gorgoulis, V. G., \& Kouloukoussa, M. (2019). Apidima Cave fossils provide earliest evidence of Homo sapiens in Eurasia. Nature, 571, 500-504.

Karkanas, P. (2001). Site formation processes in Theopetra Cave: A record of climatic change during the late Pleistocene and early Holocene in Thessaly, Greece. Geoarchaeology, 16, 373-399.

Kyparissi-Apostolika, N. (1998). The significance of Theopetra cave for Greek prehistory. In M. Otte (Ed.), Préhistoire d'Anatolie Genèse de deux mondes, Actes du colloque international, Liège, 28 avril-3 mai 1997. ERAUL 85 (pp. 241-252).

Kyparissi-Apostolika, N. (1999). The palaeolithic deposit of Theopetra cave, Thessaly (Greece). In G. E. Bailey, E. Adam, E. Panagopoulou, C. Perles, \& K. Zachos (Eds.), The palaeolithic archaeology of Greece and adjacent areas, proceedings of the ICOPAG conference, studies 3 (pp. 232-239). Athens: British School at Athens.

Lockley, M., Roberts, G., \& Kim, J. Y. (2008). In the footprints of our ancestors: An overview of the hominid track record. Ichnos, 15, 106-125.

Manolis, S. K., Aiello, L. C., Henessy, R., \& Kyparissi-Apostolika, N. (2000). The middle Paleolithic footprints of Theopetra cave (Thessaly, Greece). In N. Kyparissi-Apostolika (Ed.), Proceedings of the international conference, Theopetra Cave: 12 years of excavation and research, Trikala, 6-7 November 1998 (pp. 87-93). Athens: Greek Ministry of Culture and Institute for Aegean Prehistory.

Muller, S., Carlsohn, A., Muller, J., Baur, H., \& Mayer, F. (2012). Static and dynamic foot characteristics in children aged 1-13 years: A cross-sectional study. Gait \& Posture, 35, 389-394.

Onac, B. P., Viehmann, I., Lundberg, J., Lauritzen, S. E., Stringer, C., \& Popita, V. (2005). U-Th ages constraining the Neanderthal footprint at Vârtop Cave, Romania. Quaternary Science Reviews, 24, 1151-1157.

Pales, L. (1976). Les Empreintes de Pieds humains dans les Cavernes (Memoir 36, Archives de l'Institut de Paleontologie Humaine (Fondation Albert 1er, Prince de Monaco)). Paris: Masson.

Panagopoulou, E. (1999). The Theopetra middle palaeolithic assemblages: Their relevance to the middle palaeolithic of Greece and adjacent areas. In G. N. Bailey, E. Adam, A. Panagopoulou, C. Perles, \& K. Zachos (Eds.), The Palaeolithic archaeology of Greece and adjacent areas. Proceedings of the ICOPAG conference, studies 3 (pp. 252-265). British School at Athens: Athens.

Panagopoulou, E. (2000). The middle palaeolithic lithic assemblages of Theopetra cave: Technological evolution in the upper pleistocene. In N. Kyparissi-Apostolika (Ed.), Proceedings of the international conference, Theopetra Cave: 12 years of excavation and research, Trikala, 6-7 November 1998 (pp. 152-161). Athens: Greek Ministry of Culture and Institute for Aegean Prehistory.

Robbins, L. M. (1985). Footprints: Collection, analysis and interpretation (p. 225). Springfield: Charles C. Thomas.

Robbins, L. M. (1986). Estimating height and weight from size of footprints. Journal of Forensic Sciences, 31(1), 143-152.

Rosas, A., Ríos, L., Estalrrich, A., Liversidge, H., García-Tabernero, A., Huguet, R., Cardoso, H., Bastir, M., Lalueza-Fox, C., de la Rasilla, M., \& Dean, C. (2017). The growth pattern of Neandertals, reconstructed from a juvenile skeleton from El Sidrón (Spain). Science, 357, $1282-1287$.

Topinard, P. (1877). L'Anthropologie (Vol. 1, 2nd ed.). Reinwald: Paris. 
Trinkaus, E. (1983). Functional aspects of Neandertal pedal remains. Foot \& Ankle, 3(6), 377-390. Trinkaus, E. (2005). Anatomical evidence for the antiquity of human footwear use. Journal of Archaeological Science, 32, 1515-1526.

Valladas, H., Mercier, N., Froget, L., Joron, J. L., Reyss, J. L., Karkanas, P., Panagopoulou, E., \& Kyparissi-Apostolika, N. (2007). TL age-estimates for the Middle Palaeolithic layers at Theopetra cave (Greece). Quaternary Geochronology, 2, 303-308.

Open Access This chapter is licensed under the terms of the Creative Commons Attribution 4.0 International License (http://creativecommons.org/licenses/by/4.0/), which permits use, sharing, adaptation, distribution and reproduction in any medium or format, as long as you give appropriate credit to the original author(s) and the source, provide a link to the Creative Commons license and indicate if changes were made.

The images or other third party material in this chapter are included in the chapter's Creative Commons license, unless indicated otherwise in a credit line to the material. If material is not included in the chapter's Creative Commons license and your intended use is not permitted by statutory regulation or exceeds the permitted use, you will need to obtain permission directly from the copyright holder. 